\title{
ASSESSING KAZAKHSTAN'S PROPOSAL TO HOST A NUCLEAR FUEL BANK
}

\author{
Dmitri A. Titoff, Caitlin A. Buckley, Dmitry Novak \\ and Richard Weitz ${ }^{1}$
}

\begin{abstract}
:
Arms control advocates seek mechanisms to discourage the spread of proliferation-sensitive technologies. Most plans envision bringing nuclear fuel cycle technologies under greater multilateral control. Proposals to establish one or more nuclear fuel banks clearly fit within this framework. Under this arrangement, countries can "borrow" any fuel they need for their nuclear power reactors from a repository under IAEA control. Kazakhstan has offered to consider establishing an international nuclear fuel bank on its territory. The country has certain attributes that could make it a good candidate for a fuel bank. For example, Kazakhstan is a major player in the international uranium market, it has good relations with many countries, and its government has established a strong non-proliferation record. However, there are concerns among domestic and foreign observers about the Kazakh government's ambitious program, relations with proliferation-prone countries; and public opposition in Kazakhstan to nuclear activities.
\end{abstract}

Keywords: Nonproliferation, Kazakhstan, nuclear, Central Asia, Russia, IAEA, NPT.

\section{Resumen:}

Los defensores del control de armamentos buscan mecanismos para desincentivar la extensión de tecnologías sensibles para la proliferación. La mayoría de planes consideran situar las tecnologías del ciclo de combustible nuclear bajo un mayor control multilateral. Las propuestas para establecer uno o más bancos de combustible nuclear encajan claramente en este enfoque. Bajo este sistema, los países pueden "tomar prestado" el combustible que necesiten para sus reactores nucleares de un repositorio bajo control de la AIEA. Kazajstán ha ofrecido considerar el establecimiento de un banco internacional de combustible nuclear en su territorio. El país cuenta con ciertas características que podrían convertirlo en un buen candidato para un banco de combustible. Por ejemplo, Kazajstán es un actor destacado en el mercado internacional de uranio, tiene buenas relaciones con muchos países, y su gobierno cuenta con un historial sólido de no proliferación. Sin embargo, existe preocupación entre los observadores nacionales e internacionales acerca del ambicioso programa del gobierno kazajo, sus relaciones con países propensos a la proliferación, y la oposición de la sociedad en Kazajstán a las actividades nucleares.

Palabras clave: No proliferación, Kazajstán, nuclear, Asia Central, Rusia, AIEA, TNP.

Copyright (C) UNISCI, 2012.

Las opiniones expresadas en estos artículos son propias de sus autores, y no reflejan necesariamente la opinión de UNISCI. The views expressed in these articles are those of the authors, and do not necessarily reflect the views of UNISCI.

\footnotetext{
${ }^{1}$ Dmitri A. Titoff, Caitlin A. Buckley, Dmitry Novak and Richard Weitz (Hudson Institute) are foreign affairs analysts residing in Washington, D.C. They can be reached at datitoff@gmail.com; caitlinalyce@gmail.com; d.novak512@gmail.com and weitz@hudson.org.
}

http://dx.doi.org/10.5209/rev_UNIS.2012.n28.3840] 


\section{Introduction}

A well-known problem with the Nuclear Non-Proliferation Treaty (NPT) is that it has created a proliferation "red zone." in which its parties are legally allowed to acquire sensitive nuclear capabilities that can swiftly be transformed from producing fuel for nuclear power plants to fissile material for manufacturing nuclear bombs. As a member in good standing with the NPT and the International Atomic Energy Agency (IAEA), a state can develop extensive uranium enrichment and plutonium reprocessing capabilities while. It can then legally withdraw from the treaty by giving 90-days' notice as specified in NPT Article 10, which permits a State Party to renounce the Treaty if it "decides that extraordinary events, related to the subject matter of this treaty, have jeopardized the supreme interests of its country." North Korea has already exploited this loophole, and Iran may soon follow. Although many countries pursue uranium enrichment and plutonium separation technologies with no intentions of seeking nuclear weapons, their intentions can rapidly change for many reasons. ${ }^{2}$

To avert a world of dozens of de facto nuclear weapons capable states, the IAEA, its member governments, and various arms control advocates have sought to create mechanisms to discourage the spread of proliferation-sensitive technologies. Proposals to establish legal prohibitions against new states acquiring such capabilities have failed to gain much support since they appear to violate what states see as their "inalienable right" under NPT Article IV to pursue any nuclear technologies provided their purposes are peaceful. Confining nuclear enrichment, reprocessing, and other technologies to only a few established countries would reinforce the discrimination already present in the NPT, which allows some states to retain nuclear weapons while denying that right to others. Conversely, requiring these countries to place their existing enrichment and reprocessing facilities under international control has not been met with enthusiasm by those states that already have acquired them.

Most plans envision bringing nuclear fuel cycle technologies under greater multilateral control through market incentives in order to prevent their misuse by states that intend to acquire nuclear weapons. Establishing multilateral control over the nuclear fuel cycle would allow states to obtain nuclear fuel for peaceful purposes without incurring the financial costs or proliferation risks of making their own fuel through enrichment or reprocessing. ${ }^{3}$

Proposals to establish one or more nuclear fuel banks clearly fit within this framework. Under this arrangement, countries can "borrow" any fuel they need for their nuclear power reactors from a repository under IAEA control. A nuclear fuel bank relies on market incentives, rather than coercive methods, to encourage countries to lease nuclear fuel from designated provider states and then repatriate the resulting spent uranium fuel to the original supplier for reprocessing and disposal. These initiatives are the positive component of countries' more negative proliferation countermeasures, which emphasize denial and coercion, rather than benefits for good behavior.

The assumption underpinning proposals to establish a bank is that guaranteeing countries the right to purchase and store fuel internationally at modest cost would remove an incentive for states to develop national uranium enrichment and reprocessing capabilities that can be misused to make nuclear weapons. The presumption is that they would benefit from

\footnotetext{
${ }^{2}$ ElBaradei, Mohamed "Statement to the Sixty-Third Regular Session of the United Nations General Assembly," International Atomic Energy Agency, October 28, 2008, at http://www.iaea.org/NewsCenter/Statements/2008/ebsp2008n010.html.

${ }_{3}$ In 1946, the U.S. government proposed the Baruch Plan, which also called for international control of nuclear technologies as a means of averting national nuclear weapons programs. The Soviet government rejected it.
} 
such a bank since it would prove less costly for them economically and environmentally to acquire nuclear fuel from international sources than it would be for them to develop their own means of making reactor fuel and then storing or disposing the radioactive spent fuel and its waste. Those countries that nevertheless sought to develop their own sensitive nuclear technologies would receive special attention from the international community, since their pursuit of enrichment and reprocessing capabilities would raise concerns that non-market factors - specifically, a desire to acquire the capacity to manufacture nuclear weapons-were affecting their decision-making calculus. Some advocates of this approach push for imposing sanctions on non-participants, such as limiting their right to import nuclear technology.Most states argue that any incentives must be non-coercive. ${ }^{4}$

The IAEA, many national governments, and nuclear arms control groups and experts have supported various proposals to develop such a bank. Soon after taking office, President Barack Obama endorsed creating at least one such facility, which ideally would include nuclear fuel consisting of fissile materials from dismantled nuclear warheads. ${ }^{5}$

\section{Enter Kazakhstan}

The government of Kazakhstan has offered to consider establishing an international nuclear fuel bank on its territory. President Nursultan Nazarbaev made public his interest in possibly hosting such a bank during an April 6, 2009, joint press conference in Astana with visiting Iranian President Mahmoud Ahmadinejad. Kazakh analysts believe they could obtain several distinct benefits from hosting such a facility including strengthening the country's nonproliferation reputation, securing millions of dollars in foreign investment, and helping to develop the country's domestic nuclear infrastructure. ${ }^{6}$

Kazakhstan has certain attributes that could make it a good candidate for such a fuel bank. First, Kazakhstan is a major player in the international uranium market. The country has enormous stocks of natural uranium amounting to approximately one-fifth of the world's proven reserves.It already surpassed Canada as the world's largest national producer of uranium, and exports natural uranium to many countries. Kazatomprom, the national nuclear monopoly, announced last year that it intends to increase its share of several international nuclear energy markets. The conglomerate wants to mine 30,000 tonnes annually by 2018 . It also has set the goal of supplying $12 \%$ of the global uranium conversion market, $6 \%$ of the market for enriched uranium, and $30 \%$ of the fuel fabrication market by $2015 .^{7}$ In recent years, the company has negotiated several important joint ventures aiming to develop its national capacity with firms from China, Japan, Russia, and other countries.

Second, Kazakh officials have always supported the right of other countries to pursue nuclear energy for peaceful purposes. Many countries are justifying their decision to develop indigenous nuclear enrichment capabilities on the grounds that they do not want to become

\footnotetext{
${ }^{4}$ Carter, Ashton B. and LaMontagne, Stephen A.:"A Fuel-Cycle Fix,” Bulletin of the Atomic Scientists, January/February 2006 pp. 24-25, http://belfercenter.ksg.harvard.edu/publication/934/fuelcycle_fix.html.

${ }^{5}$ Weisman, Jonathan and Champion, Marc: "Kazakhstan Offers Nuclear Fuel Deal to U.S.," Wall Street Journal, April 5, 2009, at http://online.wsj.com/article/SB123894229162890323.html.

6 Beysenbaeva, Aygerim: “Kazak Police Foil Anti-Nuclear Demo," IWPR Central Asia, No. 573 Part 1, April $17,2009$.

7 "Uranium and Nuclear Power in Kazakhstan," World Nuclear Association, March 30, 2009, at http://www.world-nuclear.org/info/inf89.html.
} 
vulnerable to foreign suppliers for nuclear fuel, citing especially the risk of politically motivated supply cut-offs unrelated to non-fulfillment of their non-proliferation obligations. The Kazakh government's longstanding "multi-vector" policy of trying to retain good relations with all countries means that foreign governments will feel more comfortable depending on nuclear fuel provided from Kazakhstan.

Finally, since independence in 1991, the government of Kazakhstan has established a strong non-proliferation record, beginning with its decision to renounce its Soviet nuclear inheritance and continuing with its support for various international non-proliferation endeavors. Kazakhstan is a member in good standing with the Nuclear Non-Proliferation Treaty and the Nuclear Suppliers Group, which requires adherence to export guidelines designed to minimize proliferation risks. The Kazakh government has negotiated both a standard safeguards agreement with the IAEA and accepted the agency's more stringent Additional Protocol, which grants IAEA staff additional inspection and monitoring rights. Kazakhstan has collaborated with the IAEA and the U.S. government to strengthen the safety and security of its nuclear plants. ${ }^{8}$

\section{Background}

The Kazakh government is eager to expand the use of nuclear energy at home and to increase their share of what until recently was expected to be a worldwide renaissance in civil nuclear energy. Kazakhstan is developing its nuclear energy sector and technology in partnership with a number of countries. With the world's largest proven reserves of natural uranium, Kazakhstan is aiming to become a major player in the international nuclear market by partnering with other countries with advanced nuclear industries, especially Russia, to manufacture nuclear fuel and provide other nuclear services. Kazakhstan's biological and chemical sectors are much less developed. Kazakhstan's government aims to develop and strengthen its export control system as the country becomes a more influential player in the world nuclear market.

Under President Nursultan Nazarbayev, who has been in office since Kazakhstan declared independence on December 16, 1991, Kazakhstan has remained committed to a "multi-vector" foreign policy that tries to balance the influence of the great powers active in the region, promote regional political and economic cooperation through inter-regional organizations, and enhance Kazakhstan's economic development and international status. As the world's ninth largest country with a population of 15.9 million, resource-rich Kazakhstan boasts a $\$ 193.8$ billion economy - bigger than the four other Central Asian economies combined. ${ }^{9}$ It is among the world's top oil and gas producers: 25 th in gas and 18th in oil. ${ }^{10}$ Kazakhstan is also contiguous with the Caspian region believed to contain the world's largest deposits of oil and gas after the Persian Gulf and Russia. ${ }^{11}$

\footnotetext{
8 Kassenova, Togzhan: "Kazakhstan's nuclear ambitions," The Bulletin, April 28, 2008, at http://www.thebulletin.org/web-edition/features/kazakhstans-nuclear-ambitions.

9 "Kazakhstan," World Bank, at http://data.worldbank.org/country/kazakhstan; CIA: "Country Profiles: Kazakhstan," CIA World Factbook, at https://www.cia.gov/library/publications/the-world-factbook/geos/kz.html.

${ }^{10}$ Greenway, John: "Turkey's foreign and security policy: an asset for Europe," European Security and Defence Assembly, at http://www.assembly-weu.org/en/presse/articles/2010/ Turkey_EU final_Greenway.pdf.

${ }^{11}$ Lin, Christina, "The Caspian Sea: China's Silk Road Strategy Converges with Damascus," The Jamestown Foundation, September 7, 2010, at http://www.pittsreport.com/2010/09/the-caspian-sea-china $\% \mathrm{E} 2 \% 80 \% 99 \mathrm{~s}$ silk-road-strategy-converges-with-damascus.
} 
In accordance with this strategy of diversifying its partnerships with regional powers, Kazakhstan supports a U.S. economic and defense presence in Central Asia. The United States was the first country to recognize Kazakhstan, on December 25, 1991. Since then, security and non-proliferation issues have been a cornerstone in relations between the two countries. For example, the United States provided Kazakhstan with considerable financial assistance to eliminate its nuclear warheads, weapons-grade materials, and supporting infrastructure. These ties strengthened after the United States invaded Afghanistan in October 2001. Kazakh leaders immediately proclaimed solidarity with Washington in the fight against international terrorism, while the United States reciprocated by increasing its counterterrorist and counternarcotic assistance to Astana. Kazakhstan also participates in U.S. and NATO military education and training programs.

Kazakhstan's relations with the United States are important for several reasons. Kazakh officials seek American investors, especially in the energy industry but also as a key partner for Kazakhstan's efforts to diversify its economy. Hundreds of American firms now operate in Kazakhstan, with their direct net investments exceeding \$14 billion in 2009, although most of that is still placed in Kazakhstan's oil sector. ${ }^{12}$ The United States is equally interested in preventing a single state from claiming a position of economic dominance in KazakhstanIn 2009, the United States and Kazakhstan launched a Public-Private Partnership Initiative, with the participation of USAID and the U.S. Chamber of Commerce, to facilitate U.S. investment in Kazakhstan's economy, maintain stability, and ensure diversification of Kazakhstan's economic exports and partners.

Kazakhstan's relations with Western countries have remained good despite periodic American criticism of the country's de facto one-party system under the control of a strong leader. Observers and analysts consider Kazakhstan as a semi-authoritarian or suprapresidential polity that is only partially democratized. Nursultan Nazarbayev has been Kazakhstan's President since the country became independent in 1991. During the previous presidential election in December 2005, Nazarbayev won with a majority of $91 \%$. The closest runner up, Zharmakhan Tuyakbay, received $6.61 \%$ percent of the popular vote. Kazakhstan has a one-party parliament controlled by the presidential party Nur Otan. The parliament was elected in 2007, after changes introduced in May 2007 slightly enhanced parliament's powers. On June 15, 2010, parliament extended President Nazarbayev's powers, granting him life rule, immunity from prosecution, and the title of "Leader of the Nation."

Kazakh political leaders place a high value on preserving national unity, territorial integrity, and political stability even if this has placed constraints on democratic pluralism. Kazakhstan has not succumbed to the two recent global waves of regime change: the colored revolutions of the last decade that toppled the ruling groups in Georgia, Ukraine, and Kyrgyzstan; and the recent mass street protests that toppled the autocratic rulers of Tunisia, Egypt, and perhaps Libya and other Middle Eastern and North African countries. The reasons for Kazakhstan's lack of social upheavals include ethnic harmony, a genuinely popular president, and government policies that have sought to share widely the benefits of the country's recent economic growth and prosperity. Nonetheless, the Kazakh government has tried to address Western concerns about limited civil liberties and democratic freedoms by promoting political, judicial, and civil rights reforms through the government's 2009-2012 National Human Rights Action Plan and 2010-2020 Legal Concept, but critics dismiss these moves as cosmetic.

\footnotetext{
12 “Background Notes: Kazakhstan,” U.S. Department of State, at http://www.state.gov/r/pa/ei/bgn/5487.htm.
} 
Kazakhstan joined NATO's Partnership for Peace process in 1995 and began participating in NATO's Partnership for Peace Planning and Review Process in 2002. In so doing, it became the first Central Asian country to enter the program, which aims to improve the ability of its armed forces to work with NATO. Kazakhstan is also the only Central Asian country that has negotiated an Individual Partnership Action Plan with the alliance. The agreement, which came into force on January 31, 2006, provides for more extensive dialogue and specifically tailored cooperation with the alliance. It details military and political objectives and the relative contribution of both parties in achieving them. The agreement provides additional opportunities for the partners to cooperate with alliance experts, receive military training, and participate in NATO activities in such areas as defense reform, managing emergencies, and projects related to science and the environment.

Kazakhstan has allowed U.S. and other NATO warplanes to overfly its territory on a regular basis in support of alliance operations in Afghanistan. In early 2009, Kazakhstan also permitted land transit for non-military supplies. In 2010, Astana granted the United States new over flight rights for the resupply of U.S. and NATO troops in Afghanistan. This new agreement opened a direct and faster route to Afghanistan. Last July, the United States agreed with Russia to ship cargo through Russian airspace, but without being able to transit to Kazakhstan, that pact was of little use. Now, with the new Kazakhstan agreement in place, the United States can fly cargo over the North Pole, then south over Russia and Kazakhstan. Kazakhstan did refuse to participate in controversial NATO military exercises held in Georgia in May 2009. But in September 2009, NATO held its first military exercise in Central Asia, specifically in Kazakhstan. The six-day disaster response exercise, Zhetysu-2009, included 500 Kazakh and an equal number of NATO and non-Kazakh Partnership for Peace personnel.

Kazakhstan has emerged as a successful model of economic development in Central Asia and the secular Muslim world. It has the largest economy in Central Asia and its gross domestic product (GDP) exceeds the combined total of its four Central Asian neighbors. Kazakh living standards have risen considerably since independence, especially during the past decade, reaching USD $\$ 9,000$ per capita. ${ }^{13}$ In 2008, Kazakhstan's GDP per capita rose to $\$ 8,350$, compared to $\$ 5,500$ in 2006 . By 2012 , Kazakhstan plans to have increased its GDP per capita to USD $\$ 13,000 .{ }^{14}$ The country already boasts a large middle class.

The government is in the process of negotiating its entry into the World Trade Organization (WTO), and since 2006, Nazarbayev has repeatedly proclaimed the goal of transforming Kazakhstan into one of the world's 50 most-competitive developed countries, with special strengths in the energy and banking sectors. Kazakh leaders believe that strong regional cooperation -- ideally with a degree of integration that would both help harmonize regional economic policies and promote political, security, and other forms of collaboration -is essential for realizing this goal. Above all, it would allow Kazakh businesses to access new markets and exploit superior economies of scale from the resulting increase in labor, capital, and other factors of production. The Kazakh government has sought to develop extra-regional security, as well as economic, cultural, and other international links to enhance the country's global reach and autonomy.

The main source of Kazakhstan's economic prowess is its enormous energy resources. Kazakhstan is the largest oil and natural gas producer in Central Asia and in the Caspian

\footnotetext{
${ }^{13}$ Fraser, Peter, "Kazakhstan's Path Toward Democracy,” Moscow Times, February 13, 2011.

14 Committee for International Information, Ministry of Foreign Affairs of the Republic of Kazakhstan:

“Kazakhstan’s OCSE chairmanship 2010 Press Kit,” December 2009, at http://www.mfa.kz.
} 
region. It is the second-highest oil producer among the former Soviet republics. ${ }^{15}$ Kazakhstan has oil reserves of almost 5.3 billion tones. ${ }^{16}$ In 2009 , Kazakhstan produced about 560 million barrels of oil. ${ }^{17}$ At the end of 2009 , it also had 1.82 trillion cubic meters of natural gas. ${ }^{18}$ In 2010, Kazakhstan produced approximately 85 million tonnes of crude oil and gas condensate. ${ }^{19}$ The Kazakh government expected production to rise to 89 million tonnes in $2011 .^{20}$ As production at the massive offshore Kashagan oil field continues to develop over the next few years, Kazakhstan should rise into the ranks of the world's top 10 oil producers and exporters. The IEA predicts that the country's yearly output will reach about 140 million tonnes by 2020 and 190 million tonnes by 2025, stabilizing at almost 200 million tons by $2030 .^{21}$ The country also has emerged as one of the five largest grain exporters following a record harvest in 2009 of 20 million tonnes. ${ }^{22}$ Kazakhstan also has abundant reserves of barium, lead, tungsten, silver and zinc. It has the second largest global reserve of chromium, the third largest of manganese, and significant deposit of copper, gold, and iron. ${ }^{23}$

Despite recent efforts to diversify its economic partners, Kazakhstan's economy remains heavily dependent on foreign companies for capital and technology. Kazakh and foreign companies seek to exploit the natural resources and pivotal locations of Central Asia and the Caspian Basin as natural transit routes for commerce between Europe and Asia. By reducing inter-regional tensions and promoting deeper economic integration, these countries will become more attractive to foreign investors and enhance their collective leverage with external actors. Enhanced collaboration also helps counter transnational terrorist and criminal groups and helps the countries of the region to exploit their comparative economic advantages and economies of scale.

\section{Nuclear Plans and Policies}

Kazakhstan has long been a major player in the international nuclear market. The country possesses large stocks of natural uranium (approximately one-sixth of the world's proven reserves). ${ }^{24}$ Kazakhstan's nuclear industry aims to become the single largest miner and exporter of natural uranium as well as a major global supplier of uranium conversion (of uranium oxide into uranium hexafluoride), enriched uranium, and fuel fabrication assemblies. ${ }^{25}$ The government of Kazakhstan has also striven to demonstrate its commitment

\footnotetext{
15 "Kazakhstan Oil and Gas Sector," KazMunaiGas, at http://www.kmgep.kz/eng/ kazakhstan/kazakhstan_oil_and gas sector.

${ }^{16}$ BP: "BP Statistical Review of World Energy, June 2010,” BP, at http://www.bp.com/sectiongenericarticle.do?categoryId=9033088\&contentId=7060602, p. 6.

${ }^{17}$ CIA, op. cit.

${ }^{18}$ BP, op. cit., p. 22.

${ }^{19}$ Martin Sieff, "Kazakh oil production increase demonstrates confidence," Central Asia Newswire, October 7, 2010, http://centralasianewswire.com/viewstory.aspx?id=1937.

${ }^{20}$ Ibid.

21 Vatansever, Adnan: "Russia's Oil Exports: Economic Rationale Versus Strategic Gains," Carnegie Endowment, December 2010, at

http://www.carnegieendowment.org/publications/ index.cfm?fa=view\&id=42136.

${ }^{22}$ Chapman, Natalya: "Kazakhstan Grain 2009-2010, United States Department of Agriculture, December 15, 2010, at http:/gain.fas.usda.gov/ Recent\%20GAIN\%20Publications/Kazakhstan\%20Grain\%202009\%20\%202010_Astana_Kazakhstan\%20-\%20Republic\%20of_12-15-2010.pdf.

${ }^{23}$ Committee for International Information, op. cit.

24 "Uranium and Nuclear Power in Kazakhstan," World Nuclear Association, March 12, 2010, at http://www.world-nuclear.org/info/inf89.html.

${ }^{25}$ Ibid.
} 
to global nuclear non-proliferation norms. It removed all the nuclear weapons inherited upon the breakup of the Soviet Union and has supported the establishment of a nuclear-free zone in Central Asia. Yet, concerns persist about the government's commitment to protecting the safety and security of its nuclear assets. Ordinary Kazaks worry in particular about further environmental damage from domestic nuclear production activities, while Western analysts express modest concern about the country's close ties with Russia and Iran.

During the past decade, Kazakhstan has been dramatically increasing its production of uranium. From 2001 to 2009, the country's uranium output grew from 2,000 tonnes to 13,900 tonnes. Geologists have identified about 50 uranium deposits. In situ leach (ISL) mining at many locations has overtaken the output from the mining of a few hard rock deposits as the main form of production. ${ }^{26}$ With last year's record output of 13,900 tonnes, Kazakhstan produced more uranium than any other country by increasing its national output by a remarkable $63 \%$ over the previous year, which was 8,500 tonnes. Canada's 10,000 tonnes positioned it in second place in 2009, while Australia's 8,000 tonnes placed it as the thirdlargest producer. The production increase resulted from putting new uranium mines into operation and expanding the capacities of existing ones. ${ }^{27}$ The company hopes to produce 18,000 tonnes this year and 30,000 tonnes by $2018 .^{28}$

Almost all of Kazakhstan's uranium production is exported. The main destinations are Japan, China, and especially Russia. The country's domestic consumption of uranium will increase if the Kazakh government realizes its goals of expanding the domestic use of nuclear power and of becoming a producer of uranium fuel for other countries.

From 1972 to 1999, the BN-350 fast reactor at Aktau, produced electricity, heat, and desalinated sea water. It has been closed and is currently being decommissioned, with its spent fuel transferred to more secure locations. The government of Kazakhstan plans to resume domestic nuclear power production in the next few years. In addition to one or more large nuclear plants, the country's National Nuclear Centre has proposed constructing some two dozen small nuclear reactors at isolated towns in need of more electric power.

Forty companies exhibited their nuclear-related products at KazAtomExpo 2011, an international conference held in Astana from March 29-31. Almost half of the companies came from Kazakhstan, while 21 came from Russia, other former Soviet republics, and several Western countries. Duisenbai Turganov, Vice-Minister of Industry and New Technologies of Kazakhstan, said at the exhibition that Kazakhstan's nuclear power development program for 2010-2014 had been written but not yet approved by the government, which was now reviewing the Japanese crisis To enhance requirements for nuclear safety.

During the last few years, Kazakhstan and Japan have developed an extensive nuclear energy partnership. Kazakhstan supplies Japan with large quantities of natural uranium in return for substantial Japanese technical assistance to Kazakhstan in developing and constructing nuclear reactors as well as providing other nuclear services. The Kazakh representatives at KazAtomExpo 2011 acknowledged that the Japanese disaster would "have

\footnotetext{
26 “Central Asia's uranium mines”, World Nuclear Association, March 2007, at http://www.world-nuclear.org/education/mining.htm.

27“Kazakhstan takes top spot in 2009," World Nuclear News, January 5, 2010, at http://www.world-nuclear-news.org/newsarticle.aspx?id=26811\&terms=kazakhstan.

28 "Uranium and Nuclear Power in Kazakhstan." World Nuclear Association, 12 March 2010, at http://www.world-nuclear.org/info/inf89.html.
} 
a negative effect" on their export sales, but they argued that the main lesson from the Japan disaster was to avoid building nuclear power plants in earthquake zones.

\section{Nuclear Non-Proliferation}

Since their country became independent in 1991, Kazakhstan's leaders have strongly opposed the spread of nuclear weapons, including to their own country, even while supporting the safe, secure, and peaceful development of nuclear energy. With U.S. and Russian assistance, Kazakh officials eliminated or transferred to the Russian Federation all the nuclear weapons left on their soil following the Soviet Union's disintegration. This denuclearization process included the elimination of some 1,300 nuclear warheads as well as various delivery vehicles and nuclear weapons-related equipment. They also closed the Soviet-era nuclear weapons test site at Semipalatinsk, the site of hundreds of nuclear detonations that have inflicted severe costs on the surrounding environment and people.

The Kazakh government has negotiated a comprehensive safeguards agreement with the International Atomic Energy Agency (IAEA). This basic agreement, which came into force in 1994, allows the agency to monitor all the activities at the country's declared nuclear facilities. In addition, Kazakhstan has also signed the IAEA Additional Protocol. This enhanced safeguards agreement, which went into effect in Kazakhstan in 2007, grants IAEA personnel the right to monitor a wider range of possible nuclear activities as well as the right to inspect even undeclared sites where illicit nuclear activities might occur. In May 2009, Kazakhstan partnered with Russia and the United States to conduct one of the largest operations in history aimed at moving dangerous nuclear material to a more secure location. Together with the IAEA, the parties transported almost 74 kilograms of highly enriched uranium (HEU) - sufficient to construct several nuclear weapons-located in Kazakhstan to more secure storage in Russia. ${ }^{29}$ Last year, Kazakhstan and the United States completed their complex partnership to safely close Kazakhstan's BN-350 reactor, secure the weapons-grade spent fuel it had produced (sufficient to manufacture 775 nuclear weapons), and then transport the spent fuel more than 2,000 miles to secure storage sites in Eastern Kazakhstan. ${ }^{30}$

Kazakhstan's non-proliferation efforts also extend to the regional level. The country joined the Nuclear Non-Proliferation Treaty (NPT) as a non-nuclear weapons state as well as the Nuclear Suppliers Group, a voluntary body whose members pledge to support export guidelines designed to reduce the risks that transferred items could be misused for military purposes. The government of Kazakhstan has supported efforts to establish a Central Asian Nuclear Weapon Free Zone (CANWFZ). The zone was established in March 2009, following ratification by the Kazakh government of the Treaty of Semipalatinsk, signed in 2006. It covers the territories of Kazakhstan, Kyrgyzstan, Tajikistan, Turkmenistan, and Uzbekistan, obligating their nationals not to research, develop, manufacture, stockpile or otherwise attempt to obtain a nuclear explosive device. The member governments also pledged not to permit other parties from conducting such activities on their territories or to help them to do so in other locations.

\footnotetext{
29 "NNSA Announces Removal of More than 73 Kilograms of Highly Enriched Uranium from Kazakhstan," US Department of Energy, May 19, 2009, at http://www.nnsa.energy.gov/news/2372.htm.

30 "Robert O. Blake, Jr. Assistant Secretary, Bureau of South and Central Asian Affairs, Testimony before the House Foreign Affairs Committee, Subcommittee on Europe and Eurasia, Washington, DC," U.S. Department of State, March 10, 2011, at http://www.state.gov/p/sca/rls/rmks/2011/158199.htm.
} 
Kazakhstan is a leading candidate to host the world's first "nuclear fuel bank." The idea is that countries could borrow and return fuel from the repository and therefore would not need to acquire their own means of manufacturing nuclear fuel through uranium enrichment, a sensitive technology that, like the reprocessing of the "spent" (used) fuel, can be misused to make nuclear weapons. For several years, there was much international interest in seeing whether Iran might consent to rely on guaranteed access to foreign reactor fuel supplies from a nuclear fuel bank rather than incur the cost and international sanctions of developing an indigenous nuclear fuel cycle. To underscore the linkage, President Nazarbaev made public his interest inhosting sa bank during an April 2009 joint press conference in Astana with visiting Iranian President Mahmoud Ahmadinejad. As with other offers of foreign nuclear cooperation, the Iranians agreed to collaborate but not at the cost of discontinuing their own sensitive nuclear activities, leading to increased speculation that Iran is seeking the capacity to manufacture nuclear weapons.

Kazakh ambitions for nuclear services in the international market extend further. The Kazakh government and nuclear industry would like to establish a full-fledged "nuclear fuel service center" that, in addition to serving as a uranium fuel bank, could reprocess the spent fuel from nuclear reactors to recycle it as plutonium while storing the residual nuclear waste. The center could also provide nuclear reactors and other nuclear energy technologies.

\section{Export Controls}

The major components of the government's control in the nuclear export area consist of three elements: accounting, export and import controls, and physical protection. The accounting system is implemented on two levels: at the regulatory level through the Kazakhstan Atomic Energy Committee (KAEC), the country's key regulating authority in the nuclear field; and at the operational level of facilities. KAEC collects reports from the facilities and prepares reports for the IAEA; keeps supporting documentation; maintains a database of related exports and imports; and maintains a database of nuclear material inventories. Individual facilities register and process information from key measurement points and maintain a database of nuclear material accounting.

All Kazakhstan nuclear facilities are under IAEA safeguards and are subject to IAEA monitoring and inspections. Transfers of nuclear materials and technology are subject to the Law on Export Control. This law was first adopted in 1996, but it was later amended and readopted in 2007. It lists nuclear and special non-nuclear materials, related equipment, technologies, dual-use technologies, and related services as items falling under export control regulations. All these items require licenses for export and import. The law includes a socalled "catch-all" provision, which prohibits export and import operations involving any products or services that might contribute to weapons of mass destruction (WMD) and WMD delivery systems production. The law obliges exporters to apply for a license for products or services (even if they are not listed among controlled items requiring a license) in cases when they were informed by export control authorities that such products or services might be used for WMD or WMD delivery systems production or if the exporters themselves suspect this might be the case. Since 2000, Kazakhstan has maintained export control lists based on the EU model lists.

The Ministry of Industry and Trade issues the licenses for export, import and transit of dual-use products. A special State Commission on Export Control was established in 2000. 
Among important provisions of the Law on Use of Nuclear Energy (adopted in 1997, amended in 2004) are articles on accounting and control of nuclear material, and on the export and import of nuclear energy related products and services in accordance with national legislation and international treaty obligations. The law also explicitly and categorically prohibits any activities on the territory of the country that involve using nuclear energy for purposes of developing, producing, testing, storing, or proliferating weapons of mass destruction.

The Customs Code regulates customs control with a special emphasis being placed on detection of unauthorized transfer of radioactive, nuclear and other sensitive materials. The Kazakh Criminal Code provides punishment for illegal export of technologies, information or services that can contribute to WMD and WMD delivery systems. It is clear that Kazakhstan's government aims to further improve export controls and invest in developing the export control system. However, officials admit to problems connected with insufficient funding of export control programs, including a lack of qualified specialists and a lack of specialized equipment for customs and border authorities, as well as a need to strengthen law enforcement mechanisms.

\section{Current Legal Framework}

Kazakhstan's export control regime is based on the 2007 Law "On Export Control," which is derived from the 1996 "Law on export controls of arms, military hardware and dual-use goods. The Law's main objectives as stated in the Statute 4 (1) are:

- Ensuring national security

- Ensuring the non-proliferation of WMDs

- Accommodating the formation of a stable and secure system of international relations

- Strengthening international security and preventing the proliferation of WMDs and their delivery systems

Statute 4 (2) also enumerates the Law's main principles:

- Adherence to the state's international agreements with regard to the non-proliferation of WMDs, their delivery systems, and other weapon systems

- Priority of political interests over export control regulations

- Availability of information of the state with regard to export control regulations

- Inadmissibility of the support of international terrorism and extremism

- Compliance of the state's export control regime with international norms and practices 
The Law defines dual-use products as materials and technologies that can be employed both for civil and military purposes, such as production of arms and ammunition, including WMDs and their delivery systems. The Law includes provisions for end-user requirements and transit of goods subject to export controls via the state's territory. The licensing of transit goods is regulated by the separate 2008 Decree "On the Approval of Rules of Issuing Permits for Transit of Products."

Furthermore, In case of conflict between the State's international agreements and the present Law, Statute 2 asserts the supremacy of international law. The Law also requires firms to register all transactions with goods subject to export controls in a manner defined by a relevant government agency (Statute 13).

The 2008 Government Decree "On Approval of the List of Products Subject to Export Controls" lists all controlled goods. The control list was initially compiled in 2000 and was based on the lists used for export control by the European Union and the Russian Federation. The list is updated regularly to take into account amendments introduced by international export control regimes. ${ }^{31}$ Kazakhstan's control list includes all the items controlled by the Nuclear Suppliers Group, the Australia Group, the Wassenaar Arrangement, and the Missile Technology Control Regime. Most of the Central Asian and Caucasus countries have announced their intention to adopt this control list to facilitate trade and increase the effectiveness of controls. ${ }^{32}$

\section{Licensing Mechanisms}

In accordance with the 2008 Decree "On Licensing Export Import Products" the authority to license products, including products subject to export controls, lies exclusively with the Committee on Industry of the Ministry of Industry and New Technologies (former the Ministry of Industry and Trade) of Kazakhstan. The Committee's website is at www.comprom.kz.

The licensing and control of exports (imports, transit goods) relating to the nuclear sector is delegated to the Committee on Atomic Energy (www.kaec.kz). Created by Presidential Decree in May 1992, the Committee on Atomic Energy is the organization responsible for regulation of all aspects of the nuclear industry in Kazakhstan. Formerly the Kazakhstan Atomic Energy Agency (KAEA), the Committee changed its name in August 1999. It is responsible for implementing the nuclear non-proliferation regime in Kazakhstan and is the government body that is responsible for interaction with the IAEA. The primary functions of the Committee are as follows: regulation of all aspects of the use of nuclear energy, including licensing activities in the sphere of nuclear energy and inspections to ensure compliance with nuclear safety regulations; state control and accounting of nuclear materials; control of the export and import of nuclear materials and technologies, special non-nuclear materials, and dual-use materials to prevent the proliferation of nuclear weapons; accident readiness, and organization of physical protection of nuclear materials and facilities.

\footnotetext{
31 "Kazakhstan: National dual-use export control system," Stockholm International Peace Research Institute, at http://archives.sipri.org/contents/expcon/kazakhstandu.html.

32 "Testimony of Matthew S. Borman, Deputy Assistant Secretary of Commerce for Export Administration Before the Senate Governmental Affairs Subcommittee on International Security, Proliferation, and Federal Services," Bureau of Industry and Security U.S. Department of Commerce, November 29, 2001, at http://www.bis.doc.gov/news/archive2001/bormantmonysgovaff112901.htm.
} 
KAEA came under the jurisdiction of the Ministry of Science and New Technologies in October 1995, and became subordinate to the Ministry of Science-Academy of Sciences under the terms of an 11 March 1996 presidential decree. In January 1999, the Ministry of SciencesAcademy of Sciences became the Ministry of Science and Higher Education. Following the cabinet reorganization of 13 October 1999, oversight of the Committee on Atomic Energy was transferred from the Ministry of Science and Higher Education to the Ministry of Energy, Industry, and Trade. The Committee was subsequently transferred to the Ministry of Energy and Natural Resources in December 2000.

In order to apply for a license to export products a firm must submit, in addition to basic information, the following materials:

- Import-export contracts between economic actors for products subject to licensing and export controls

- Contracts between the exporter and manufacturer (or importer and consumer) for goods subject to licensing and export controls

- Licenses granting a firm the right to carry out activity with goods and products that require licensing in the internal market

- Permits from relevant government agencies, designated in the list of products subject to licensing and export controls

- Original end-user certificates issued by a relevant government agency of the recipient state, which agrees to use imported products (subject to export controls) only for internal needs and not to re-export to a third party without the permission of Kazakhstan. (The Foreign Ministry of Kazakhstan observes the compliance with enduser certificates)

Fig. 1. Agencies involved in issuing permits for and coordination of export license applications for goods subject to licensing and export controls

\begin{tabular}{|l|l|}
\hline Arms and other military equipment & Committee on State Security, Foreign Ministry \\
\hline $\begin{array}{l}\text { Nuclear materials, technologies and equipment; } \\
\text { sources of radiation and nuclear waste }\end{array}$ & $\begin{array}{l}\text { Committee on Atomic Energy of the Ministry } \\
\text { of Energy and Mineral Resources }\end{array}$ \\
\hline Officinal drugs & Ministry of Agriculture \\
\hline Phosphorus & Ministry of Environmental Protection \\
\hline Products subject to export controls & $\begin{array}{l}\text { Committee on State Security, Ministry of } \\
\text { Education }\end{array}$ \\
\hline Cryptography products & Committee on State Security \\
\hline Explosives & Ministry of Interior \\
\hline
\end{tabular}


Rare earth materials, raw materials, alloys, etc.

Committee on Atomic Energy of the Ministry of Energy and Mineral Resources

X-ray equipment, medical equipment containing radioactive elements and isotopes

Ministry of Health

Industrial Waste

Ministry of Environmental Protection

Fig. 2. Structure of Export Control in Kazakhstan ${ }^{33}$

\section{Structure of Export Control in the Republic of Kazakhstan}

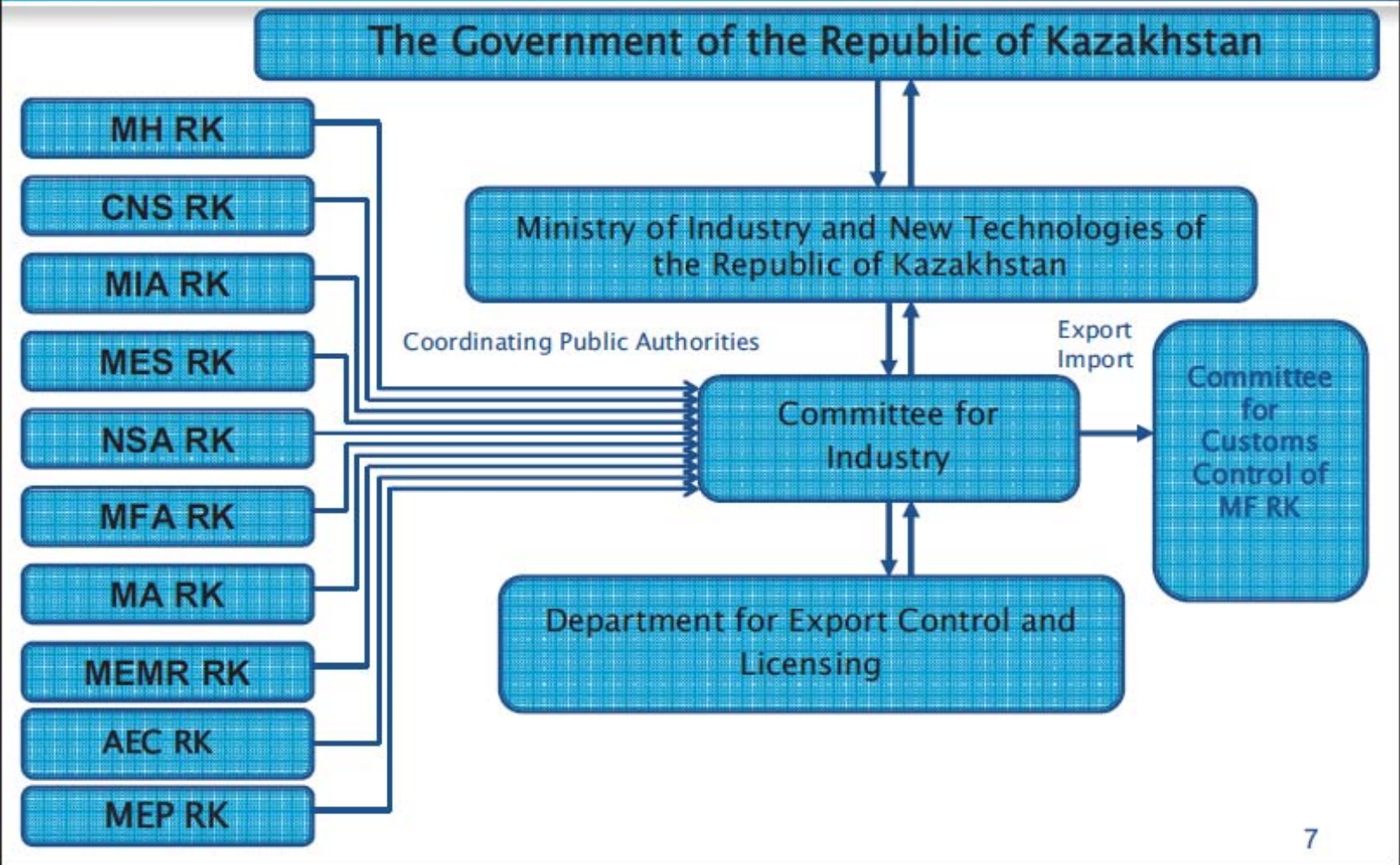

\section{Enforcement and Compliance}

Kazakhstan's Customs Control Agency monitors the transit of goods across Kazakhstan's border and is the primary enforcer of the state's export control regulations. The Customs Code regulates customs control with a special emphasis placed on the detection of unauthorized transfer of radioactive, nuclear, and other sensitive materials.

33 "OSCE Workshop to Identify the Proper Role of the OSCE in Facilitation of UN Security Council Resolution1540," January 27, 2011, at http://www.osce.org/fsc/75186. 
The Foreign Ministry observes whether actors are in compliance with end-user certificates.

The Committee on Atomic Energy coordinates applications for export, import, and transit licenses for products related to the nuclear sector. The Committee decides whether to approve the license application only after comprehensive evaluation of export routes and reliability of end user of the products as well as examination of a declaration from the importing state in a case where the state does not host nuclear weapons. ${ }^{34}$

All firms licensed to export controlled products submit an annual report to the Committee on Atomic Energy, which must include specific information on internal export controls ("must not be declaratory in character"). In accordance with conditions of the license issued by the Atomic Energy Committee, before 31 January, every enterprise should present to the Committee a report on its activities in the previous year and must have the following structure:

- Title page

- General information about the organization

- Brief description of licensed activities and changes in these activities

- Information about incidents and radiation accidents that have occurred during the reporting period

- The following forms (depending on the type of the organization)

- L-1/O - General information about the organization, including the names and addresses of subsidiaries, number of employees, type of activity, etc.

- L-2/O - Information about the personnel responsible for ensuring radiation security in the organization (names and contact information).

- L-3/O - Information about licenses held by the organization (including import/export licenses).

- L-4/O - Information about third-companies that are contracted by the organization to conduct: personal dosimetry, personnel insurance, equipment maintenance, and radiation control.

- L-5/O - Information about government inspections/calibrations of dosimetry equipment.

- L-6/O - Information about other organizations that are contracted by the organization to provide services that fall within the scope of the organization's licensed activities.

- $\quad$ L-7/O - General information about radiation sources and equipment emitting ionizing radiation.

\footnotetext{
34 “Export-Import," Committee on Atomic Energy, at http://www.kaec.kz/rus/export.
} 
- L-8/O - General information about the transportation, deliveries and sale of the sources of ionizing radiation.

- $\quad$ L-9/O - General information about the production and sale of the sources of ionizing radiation.

- L-10/O - General information about radionuclide sources that have been transferred and accepted for long-term storage in specialized organizations.

- L-11/O - Information about personnel training. ${ }^{35}$

In essence, the requirements for the reports are that they must give the Committee authentic and full information, sufficient for the evaluation of radiation safety conditions in the organization during the reporting period. If the organization fails to submit the Report before deadline, the Committee has the right to apply sanctions within its competence.

The 2007 Decree \#1375, “On the Approval of Qualified Requirements for the Firm's Internal Export Control," requires firms to have:

- Explicit export control rules;

- An internal export control plan;

- A scheme illustrating export control mechanism used by a firm and how this mechanism interacts with other parties, including foreign parties;

- A training plan for personnel involved in export activities; and

- A system of accounting regarding controlled goods.

According to Statute 12 of the 2007 Law “On Export Control”, appropriate government agencies conduct pre-export inspections and collect information to ensure the compliance with export control regulations.

Statute 13 of the 2007 Law "On Export Control" requires that firms keep a record of external transactions for export control purposes. The record of transactions must be kept for a minimum of five years, unless a law states otherwise. Record keeping rules relating to the external transactions of controlled goods are defined by a relevant government agency.

Statute 16 of the Law authorizes agencies to request information from firms relevant to export control to be used by government agencies exclusively for export control purposes and in a confidential manner to protect trade secrets and other sensitive information.

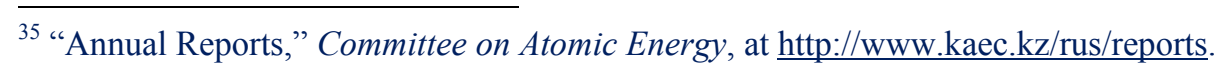




\section{Nuclear Sector}

Kazakhstan Atomic Energy Committee is the Nuclear Regulatory Body of the Republic of Kazakhstan. The principal fields of activity of the National Nuclear Center of the Republic of Kazakhstan are radioecology, nuclear power engineering and NPP safety, nuclear physics and radiation material science, nuclear-physical methods and high-end technologies, geophysics and non-proliferation, and personnel training. The NNC includes: the Institute of Nuclear Physics, the Institute of Atomic Energy, the Institute of Geophysical Research, the Institute of Radiation Safety and Ecology, the Baikal Enterprise, and the Kazakh State Research and Production Center of Explosive Operations.

\section{Fig. 3. Organization of National NP Program ${ }^{36}$}

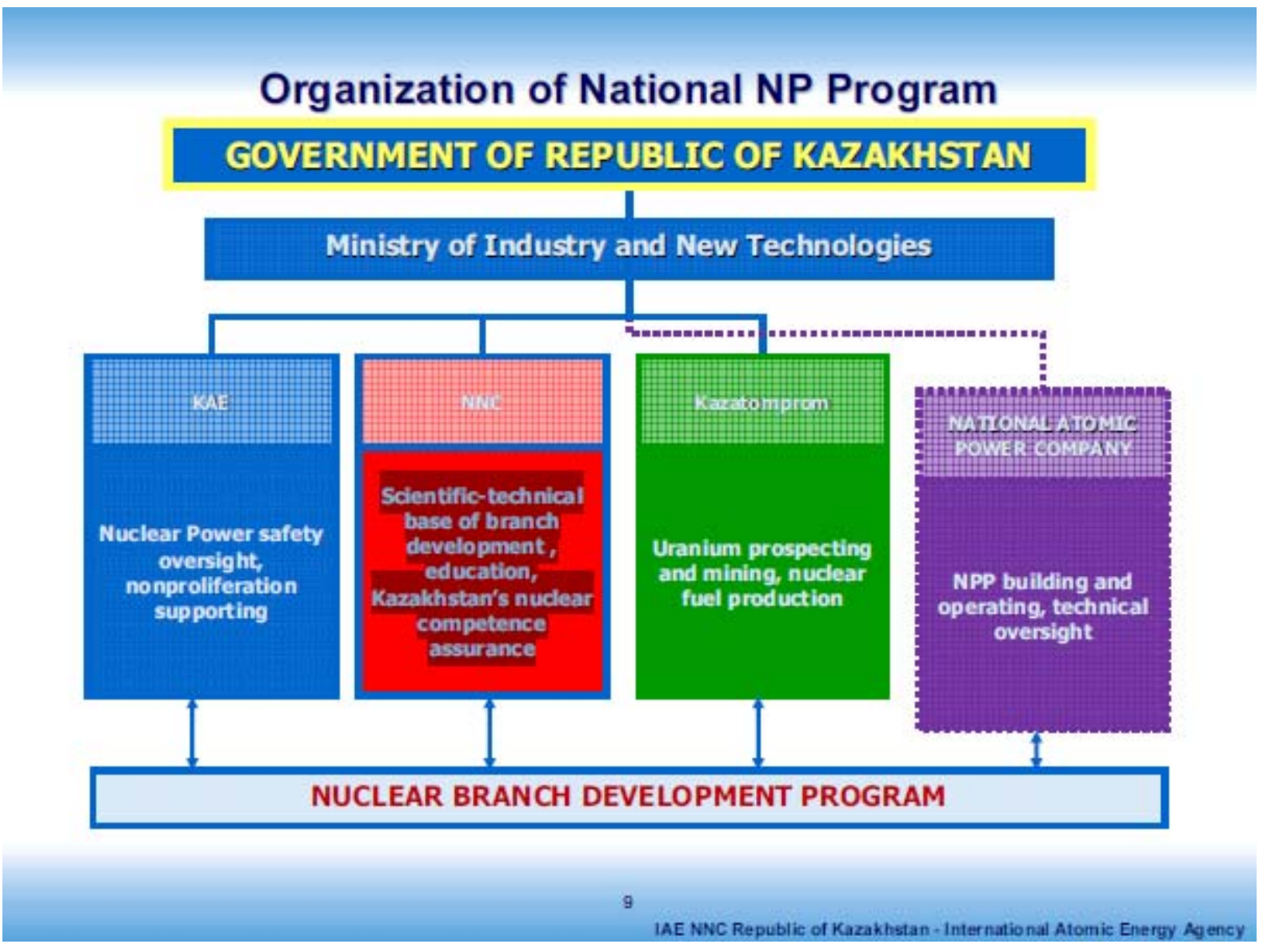

\footnotetext{
${ }^{36}$ Kenzhin, E. and Vurim, A.: "Current Status of Nuclear Power Introduction in Kazakhstan," Current Status of Nuclear Power Introduction in Kazakhstan, International Atomic Energy Agency, Institute of Atomic Energy, National Nuclear Center, Republic of Kazakhstan, Vienna, June 14-17, 2010, at http://www.iaea.org/NuclearPower/Downloads/INPRO/Files/2010-June-IR-WS/Kazakhstan-Presentation-forVienna-IAEA 08-06-2010.pdf.
} 


\section{KazAtomProm}

KazAtomProm is a wholly state owned company, established in 1997, that controls all uranium exploration and mining in Kazakhstan as well the country's other nuclear-related activities, such as the export or import of nuclear materials.

According to Kazatomprom's 2010 annual report, uranium production by all producers in Kazakhstan increased by almost 30 percent, with 17,803 tonnes of uranium being extracted. The volume of uranium mining in the country doubled last year. Excluding subsidiaries and joint ventures, the Kazatomprom sold some 9,000 tonnes of uranium, while the value of orders to the company at the end of 2010 reached US \$17 billion. In 2010, Kazatomprom's net profit amounted to about KZT 53 billion, 24 percent more than in 2009 (KZT $147=$ US\$1). Kazatomprom plans to invest more than KZT 341 billion in diverse projects during the next five years. ${ }^{37}$

Kazatomprom's holdings include 20 enterprises working in the nuclear industry. Its affiliated companies are $^{38}$ :

- Akbastau

- APPAK

- Baiken-U

- Betpak Dala

- Geotechnology

- Kazatomprom-Demeu

- KATCO

- Karatau

- Kyzylkum

- Kyzyltu

- Mining Company

- MAEC-Kazatomprom

- Nuclear Stations JSC

- Semizbai-U

- SAP-U

37 "Uranium Development Set for Growth on Back of Good Results in 2010," Kazakh Foreign Ministry, February 11, 2011.

38 "Affiliated Companies," Kazatomprom: National Atomic Company, at http://www.kazatomprom.kz/ en/pages/Akbastau. 
- Stepnogorsk Mining-Chemical Complex

- The Kazakhstan Nuclear University

- The Institute of High Technologies

- Volkovgeology

- Ulba Metallurgical Plant

- Uranenergo

- Zarechnoye

All KazAtomProm subsidiaries (http://www.kazatomprom.kz/en/pages/Akbastau) carry out mining activities individually. They also sell products individually - all have licenses to export activity. In order to obtain a license, they need to develop intra-company programs of export control, describing who is responsible for what (basically a form of ICP). In order to export, an additional and separate license is required- i.e. companies should have (1) a general license for activity, and (2) a license specifically for exports. Before any delivery, companies have to inform the Committee of Atomic Nuclear Energy of the delivery. A follow-up post-delivery is also required. KazAtomProm supervises affiliated companies, monitors andcarries out inventory checks on the individual subsidiaries -5 or 6 KazAtomProm personnel visit each enterprise to check the inventory of uranium materials. KazAtomProm only delivers uranium to certain defined countries - Russia, France, China, US, Canada, Argentina, and India.

Subsidiaries of KazAtomProm and their shareholders can develop distinct marketing and sales strategies, but they must correspond with KazAtomProm's general policy. KazAtomProm conducts all physical shipments - each subsidiary company has an exclusive agreement with KazAtomProm for rendering export services. Although KazAtomProm is a national organization functioning on behalf of the government $(100 \%$ state-owned), its subsidiary companies and enterprises have various private shareholders - KazAtomProm has a varying stake in each of them. The presence of other shareholders in each subsidiary does not alter KazAtomProm's fundamental control and supervision of the nuclear sector in Kazakhstan.

KazAtomProm aims to become a vertically integrated company involved in all phases of the nuclear fuel cycle. ${ }^{39}$ In 2008, the company managers announced their goals of supplying $30 \%$ of the world's demand for uranium, $12 \%$ of the international market for uranium conversion, $6 \%$ of the global demand for uranium enrichment, and $30 \%$ of the market for fabrication of fuel assemblies by $2015 .^{40}$ To realize this goal, KazAtomProm has negotiated joint ventures with firms from countries having advanced nuclear technologies, including Russia, China, Japan, Canada, and South Korea.

\footnotetext{
39 "Progress in Kazakh ambitions," World Nuclear News, 12 August 2009, at http://www.world-nuclear-news.org/newsarticle.aspx?id=25806\&terms=kazakhstan.

40 "Uranium and Nuclear Power in Kazakhstan," World Nuclear Association, February 25, 2010, at http://www.world-nuclear.org/info/inf89.html.
} 
In 2006, KazAtomProm signed several joint venture agreements, worth some $\$ 10$ billion, with Russia's leading nuclear energy firms. ${ }^{41}$ The agreement with AtomStroyExport to develop and market innovative small and medium-sized nuclear reactors has not yielded many results. The second, with Russia's Techsnabexport (Tenex), provides for the expansion of a small uranium enrichment plant that will eventually enrich 6,000 tonnes annually of the uranium that Russian-Kazakh joint ventures mine in Kazakhstan. In addition, KazAtomProm acquired a 10\% interest in the Angarsk International Uranium Enrichment Centre, the formal name for the joint stock company in which Tenex holds a majority of the shares. In 2006 and 2007, China Guangdong Nuclear Power Group Holdings (CGNPC) signed agreements with KazAtomProm on supplying uranium and fuel assemblies to China and on investing in China's nuclear energy sector. In 2007 and 2008, Kazakhstan and Japan signed several agreements. Under their terms, Kazakhstan agreed to supply uranium to Japan while Japanese firms offered to help Kazakhstan develop its fuel-cycle, fuel-fabrication, and reactorconstruction technologies. Both CGNPC and the China National Nuclear Corporation are investing in uranium mines in Kazakhstan. The government of Kazakhstan has signed several nuclear energy cooperation agreements with other governments, including EU members and the United States.

KazAtomProm has been investing in foreign nuclear corporations-buying a $10 \%$ share in Westinghouse/Toshiba - and collaborating with Canada's Cameco Corporation to create the Ulba Conversion LLP, a joint venture in which KazAtomProm owns $51 \%$. It is building a uranium hexafluoride (UF6) conversion plant at the Ulba Metallurgical Plant in UstKamenogorsk. ${ }^{42}$ Kazakhstan already has a major plant at Ulba which was one of the enterprises established during the Soviet period. The plant produces a small quantity of nuclear fuel pellets from uranium enriched in Russia and is looking for new markets, especially in China and Japan). Currently the pellets are primarily used in Russian and Ukrainian reactors. The plant also makes fuel pellets for Western reactors from reprocessed uranium. $^{43}$

KazAtomProm is receiving additional fuel fabrication technology through a strategic partnership with France's state-owned Areva. KazAtomProm and Areva have established the Katco joint venture, while Areva has pledged to help Kazakh engineers build fuel fabrication production lines at KazAtomProm's metallurgy plant in Ulba. The facility will have the capacity to produce 1,200 tonnes each year, of which a third will be reserved for making fuel for French-designed reactors. ${ }^{44}$ KazAtomProm is also trying to participate in the back-end of the nuclear fuel cycle by partnering with Russia in designing and constructing nuclear reactors. The initial joint project is to design the VBER-300 reactor for use at Aktau in Kazakhstan. In April 2009, KazAtomProm signed a preliminary memorandum of understanding with CGNPC to assess the feasibility of forming a joint venture that would specialize in constructing nuclear power reactors for use in China. ${ }^{45}$

\footnotetext{
41 Ibid.

42 "Progress in Kazakh ambitions," op. cit.; "Canada and Kazakhstan agree nuclear cooperation," World Nuclear News, September 25, 2009, at

http://www.world-nuclear-news.org/ newsarticle.aspx?id=26179\&terms=kazakhstan.

43 "Uranium and Nuclear Power in Kazakhstan," op. cit.

44 "Progress in Kazakh ambitions," op. cit.

45 “Kazakhstan takes top spot in 2009," World Nuclear News, January 5, 2010, at http://www.world-nuclear$\underline{\text { news.org/newsarticle.aspx?id=26811\&terms=kazakhstan. }}$.
} 
KazAtomProm and its subsidiaries apply to the Ministry of Industry and New Technologies (MINT), which carries out background checks into company (over a maximum 30-day period). Other enterprises apparently come to KazAtomProm for technical and other assistance in meeting these regulatory standards in order to avoid negative license application results.

\section{International Cooperation}

Fig. 4. Participation of Kazakhstan in multilateral contracts and agreements in the area of non-proliferation, disarmament and control over armaments

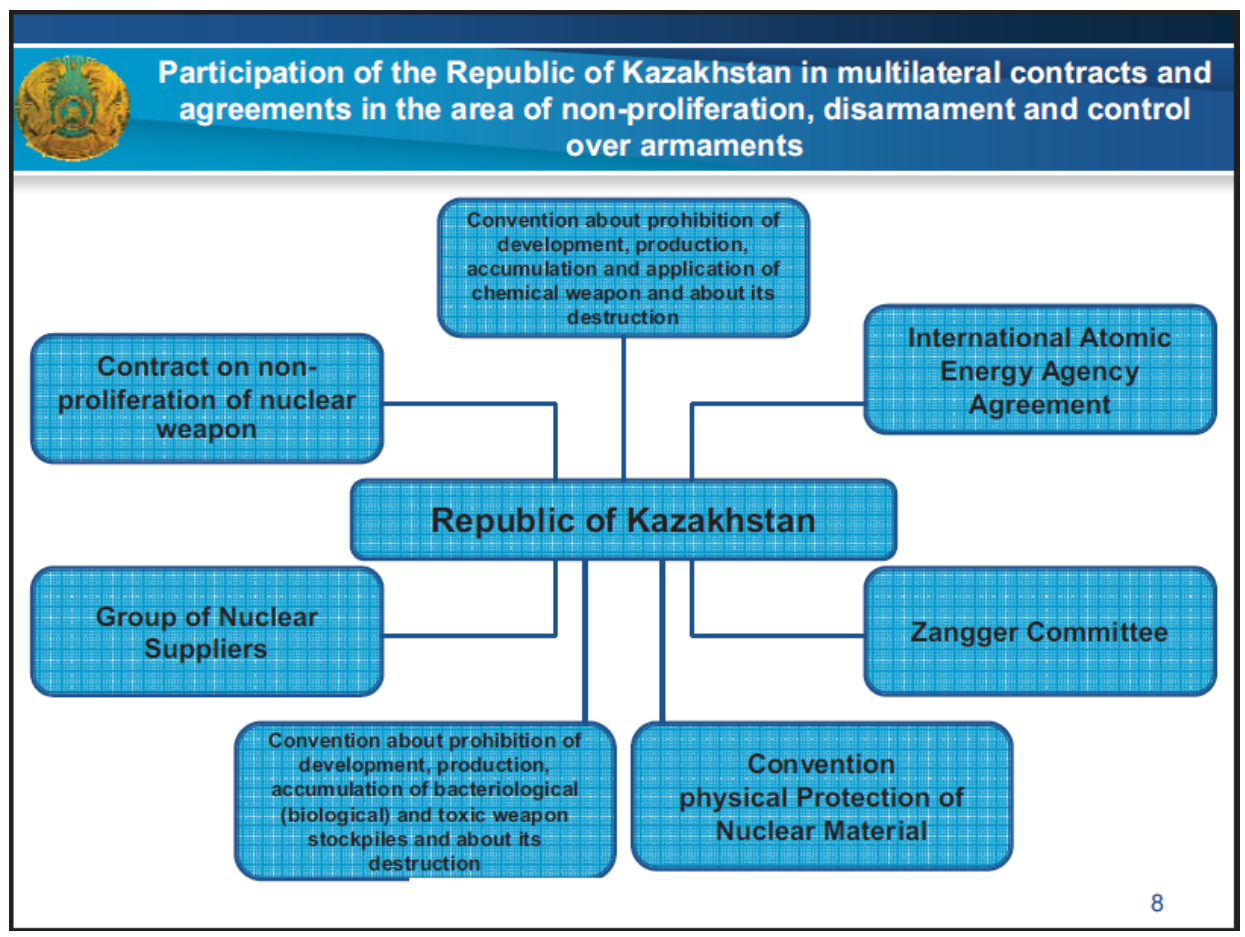

Kazakhstan is a party to major international export control regimes, including The Hague Code of Conduct against Ballistic Missile Proliferation, the Group of Nuclear Suppliers, the Proliferation Security (Krakow) Initiative, and the Zangger Committee. Kazakhstan is taking steps to join the Austrian group and the Missile Technology Control Regime. The IAEA, the United States, and other institutions have trained many of Kazakhstan's nuclear specialists through courses on security, physics, etc. The country's customs agents and others have also been trained in identifying and tracking dual-use goods.

\section{Nuclear Technology Safety Center (NTSC)}

The NTSC was established in 1998 to support the development of the nuclear sector in Kazakhstan (with support from the U.S. Department of Energy). It provides technical support to MINT, including the Committee of Atomic energy, and is responsible for developing draft documentation for that Committee (e.g. on handling of used / spent fuel, use of sites for 
nuclear power plants). NTSC does not provide any technical support on licensing. It is akin to a non-governmental organization, but received some government funding by participating in some open tenders and organizational direction from government bodies. NTSC has been working in this area for 10 years in three areas: (1) licensing (to some extent); (2) working with nuclear facilities; and (3) enforcement. It helps to develop modal Internal Compliance Programs (ICPs), which are basically templates that companies use in developing their own ICPs. For instance, all KazAtomProm subsidiaries have ICPs. NTSC has developed materials and seminars for various training programs on export control issues. NTSC has tried to expand these seminars beyond nuclear into biological and chemical sectors as well. NTSC has also been trying to develop and take on a leadership function in educating customs officials. To achieve this goal, NTSC has partnered with 26 Kazakh universities and institutions to train customs officials. They have worked with the Pacific Northwest National Laboratory in Washington State (which have helped develop training material for NTSC specifically focused on the Kazakh context). NTSC is heavily focused on Commodity Identification Training and strives to establish so-called "identification centers," of which there are about 20 in the Russian Federation.

\section{Ministry of Industry and New Technologies (MINT)}

MINT is an executive body that regulates the state's industry and innovation spheres, R\&D, metallurgy and raw material extraction, machinery, chemical and pharmaceutical industries, and related activities. The Ministry regulates safety, technical and other standards; export controls; use of atomic energy; renewable energy; geological exploration, and related activities. It was created by government decree \#416 (2010). Aset Isekeshev was nominated to be the head of the MINT in 2011. He also serves as the Deputy Prime Minister.

The Ministry currently consists of:

- The Committee on Investments

- The Committee on Industry

- The Committee on Technical Regulation and Metrology

- The Committee on State Energy Supervision

- The Committee on Atomic Energy

- The Committee on Geology and sub-soil use

The Ministry's general tasks consist of:

- Participation in the formulation of the state's politics in the spheres of industry, innovation, and technology

- Coordination of relevant activities among other state agencies 
- Creation of conditions for the development of the state's economy on the basis of the introduction of technological products and formation of high technology enterprises

- Stimulation of innovation through the creation of organizational and economic conditions facilitating the realization of the State's innovation policies

- Creation of an auspicious innovation climate

- Ensuring measures for the realization and monitoring of innovation projects

- Coordination of processes of the diversification and forced industrialization of the economy

In terms of activities, MINT

- Develops the list of goods and services subject to export control

- Issues end-user certificates for foreign companies

- Issues transit permits

- Issues final reports on whether certain products are subject to export controls

- Controls the export, re-export, import, re-import, transit and processing of goods beyond the State's borders

In MINT's approach, international standards take precedence over national regulations. MINT issues 2,000 annual licenses for trade of controlled goods (military equipment and dual-use items). Around 300 licenses are issued annually for dual-use - uranium products, some military import-export items, and explosives. MINT is currently undertaking an effort to develop a register of enterprises (at the local level) to clarify who is producing what. The State Program of Innovative Development aims to develop key industry sectors in Kazakhstan, including pharmaceuticals and chemicals to reinforce national development and investment in these sectors. The space sector is another key target for development, but serious impediments, including an absence of membership in the Missile Technology Control Regime (MTCR), has resulted in limited production.

\section{Republic State Enterprise Kazspetsexport (KASPEX)}

KazSpetsExport [http://www.kaspex.kz/] operates as an agency under the Minister of Defense (MPD) and governs with sole authority the import and export of military equipment. Its focus is on intermediary services - essentially acting as a state mediator between sellers and buyers. No independent companies in Kazakhstan have the authority to export on their own, free from KazSpetsExport regulation. The foreign purchase of any military equipment requires a license. KazSpetsExport bases their licensing activities on legislation No. $300-3$ (21 July 2007) amended in 2009 and 2010. All imports and exports of military equipment/dual-use 
items are conducted under the framework of this legislation, and must also comply with international standards, obligations, and embargoes. The Customs Authority and MINT implement the transit of dual-use items through Kazakhstan.

When responding to a request for military equipment and brokering such a deal, KazSpetsExport does not arbitrarily choose producers. KazSpetsExport does not make a judgment on who is the best to respond to a requirement for military equipment - there are a series of producers that are all considered by KazSpetsExport. The decision on which company to engage, is based on price considerations and compliance to international regulations. KazSpetsExport has a special division that monitors and covers defense industry exhibitions, which KazSpetsExports also participates in, in order to identify the best producers. The exhibitions are also a chance for the analytical division of KazSpetsExport to examine industry presentations and briefings. Kazakhstan Engineering and MINT have a record of all companies producing military and dual-use items.

\section{Risks and Challenges}

Despite Kazakhstan's good proliferation record certain domestic and international concerns about Kazakhstan's hosting a multinational nuclear fuel bank persist. Public opposition to nuclear activities remains high in Kazakhstan given the horrific legacy the country inherited from the Soviet Union. During the Cold War, the Soviet government used the Semipalatinsk facility in eastern Kazakhstan to test hundreds of nuclear bombs, which polluted much of the surrounding environment and left thousands of people suffering adverse medical consequences. One of the first actions of the newly independent Kazakh government was to close the site and negotiate the return or elimination of the nuclear weapons and nuclear delivery vehicles (such as long-range missiles) that Kazakhstan inherited following the Soviet Union's collapse. Timur Zhantikin, chairman of the Kazakh Atomic Energy Committee, has said that ensuring the country's ecological and environmental security would be the government's principal concerns in deciding a location and construction program for a possible nuclear fuel bank. ${ }^{46}$ Even so, some domestic groups believe that the country's authoritarian government would keep the facility's operations secret and conceal any risks and accidents. ${ }^{47}$ Some foreign observers might worry about the close ties between the Kazakh government and Russia and Iran, especially since Moscow and Tehran are seeking to develop a robust nuclear partnership. The recent scandal surrounding the arrest of the head of Kazatomprom, the national nuclear monopoly, and some of his associates has reinforced concerns that corruption might contribute to the diversion of sensitive nuclear materials to criminals or terrorists. ${ }^{48}$ Nuclear experts also are unsure whether the Kazakh government can train a sufficient number of skilled operators to manage the rapid expansion of the national nuclear industry envisaged by current plans. ${ }^{49}$

During the 1990s, due to high turnover of personnel and agencies with export control authority in Kazakhstan, a lack of institutional memory and resources presented problems for

\footnotetext{
46 "Kazakhstan studies plan to host nuclear fuel bank," China View, May 18, 2009, at http://news.xinhuanet.com/english/2009-05/18/content 11397532.htm

${ }^{47}$ Beysenbaeva, Aygerim: “Kazak police foil anti-nuclear demo," IWPR Central Asia, No. 573 (2009), Part 1.

${ }^{48}$ Pannier, Bruce: "Kazakh Atomic Kingpin Suddenly Radioactive," Radio Free Europe/Radio Liberty, May 27, 2009, at http://www.rferl.org/content/Kazakh_Atomic Kingpin_Suddenly Radioactive/ 1740290.html.

${ }^{49}$ Kassenova, Togzhan: "Kazakhstan's nuclear ambitions," The Bulletin, April 28, 2008, at http://www.thebulletin.org/web-edition/features/kazakhstans-nuclear-ambitions.
} 
Kazakhstan's export controls. . Since 1993, the central export control authority, currently known as the Office of Import and Export Controls, has been subordinate to four different ministries: the Ministry of Foreign Economic Relations (MFER) in 1993; the Ministry of Industry and Trade from 1994 to 1997; the Ministry of Energy, Industry, and Trade from 1997 to 2000; and, since December 2000, the Ministry of Economy and Trade. The move of the Kazakhstani capital from Almaty to Astana in December 1997 further interfered with the country's export control system. Some reviewing agencies, such as the Committee on Atomic Energy, have chosen not to move, which has led to fewer opportunities for face-to-face consultation between reviewing agencies and the Office of Import and Export Controls. It is unclear whether the government itself is aware of the impact such disruptions have on the frequently reorganizing institutions. ${ }^{50}$

Currently, the primary problem affecting licensing procedures in Kazakhstan is the volume of license reviews and approvals. The MINT deals with some 40 applications per day. Enterprises often complain of delays in receiving sufficient guidance and information from MINT.

Despite Kazakhstan's solid non-proliferation record, many domestic and foreign observers worry about the government's unbridled nuclear ambitions. At home, many Kazakhs still suffer from nightmares about the Soviet era, when Moscow exploited Kazakhstan as a source of natural uranium and, more alarmingly, a convenient location to test the Soviet Union's expanding arsenal of nuclear weapons. The people living near the nuclear testing complex at Semipalatinsk in eastern Kazakhstan witnessed hundreds of nuclear detonations with minimal safety equipment, leaving thousands of them with a polluted environment and severe medical consequences. Environmentalists and other civic action groups have expressed concern that the government will accept lax safety standards, conceal accidents, and downplay other environmental dangers that could threaten its ambition of transforming Kazakhstan into a world leader in the nuclear energy market. It takes much less time to open a uranium mine in Kazakhstan than in Western countries where the environmental and other regulations are stricter. ${ }^{51}$

A scandal surrounding the arrest of the head of KazAtomProm and some of his associates reinforced domestic and foreign concerns that corruption might corrode ecological regulations and provide opportunities for criminals or terrorists to acquire and misuse nuclear materials or technologies from Kazakhstan. ${ }^{52}$ The government has adopted all the necessary laws and regulations to establish a good legal framework for export controls, but outsiders wonder whether they will be enforced if the recipient can bribe corrupt officials to ignore them. $^{53}$

Although the Soviet era did help modernize Kazakhstan's education system, there are also worries that the Kazakh government will not be able to train enough skilled technicians to oversee the planned rapid expansion of the national nuclear industry. ${ }^{54}$ Conversely, fears

\footnotetext{
${ }^{50}$ Wolfe, Keith D.: “An Evaluation of Export Control in Kazakhstan," Center for International Trade and Security Web Site, at http://www.cits.uga.edu.

51 "Uranium and Nuclear Power in Kazakhstan," World Nuclear Association, March 12, 2010, at http://www.world-nuclear.org/info/inf89.html.

${ }_{52}$ Pannier, op. cit.

${ }^{53}$ Parish, Scott and Robinson. Tamara: "Efforts to Strengthen Export Controls and Combat Illicit Trafficking and Brain Drain," The Nonproliferation Review (Spring 2010), pp. 112-124, at http://cns.miis.edu/npr/pdfs/parish71.pdf.

${ }^{54}$ Kassenova, op. cit.
} 
exist that the growing number of Kazakh nuclear specialists might sell or rent their expertise to criminals, terrorists, or foreign governments seeking nuclear knowledge for illicit purposes.

Western governments worry that Kazakhstan will serve as a stocking horse for Russia's own ambitions. For example, they worry that the Semipalatinsk Protocol, which is open for signature by the declared nuclear weapons states, can be read as allowing Russia to move nuclear weapons into or through the Central Asian Nuclear Weapons Free Zone (CANWFZ) since it declares that the zone's establishment does not affect the parties' existing international obligations, a phrase that could be interpreted as grandfathering the Collective Security Treaty (CST), under which Russia can protect Kazakhstan and other signatories with its nuclear weapons. Despite Kazakhstan's cultivation of new nuclear partnerships, the country remains dependent on Russian fuel enrichment facilities for the foreseeable future even as it develops indigenous capabilities for the two precursor phases of the nuclear fuel cycle-uranium conversion and the production of fuel assemblies.

Doubts also exist about the extent to which Kazakhstan will confront Iran about its suspect nuclear activities. Kazakh leaders have denounced North Korea for its nuclear weapons tests, but have refrained from criticizing Tehran for pursuing nuclear enrichment and other activities that the UN Security Council has termed illegal and the IAEA has now assessed as potentially intended to develop nuclear weapons.

For their part, Kazakhstani authorities would like greater transparency of the U.S. government's export control system in order to establish their own systems based on U.S. best practices and lessons learned.

Whether the economy will continue to prosper is also uncertain. Nazarbayev and his team have strived to use a large part of the country's windfall energy revenue to develop other economic sectors and to promote education and technical training. Nonetheless, events during the past few years, when Kazakhstan was severely affected by the global economic downturn, show that the country's prosperity for at least the next decade will remain heavily dependent on world energy prices and the health of the international economy.

Another uncertainty is how Kazakhstan's entry into a new customs union with Russia and Belarus will affect its economic autonomy. The union eliminates tariff and non-tariff barriers for trade in goods and services between the parties. Those managing the customs union may seek to develop a uniform exports control policy, which could affect (positively or negatively) the strength of Kazakhstan's export controls. Russian firms earn billions of dollars each year through the export of weapons and dual-use items, and would presumably fight to reduce any restrictions associated with Kazakhstan. That said, Kazakhstan's export control is primarily focused on regulating uranium production and export.

Kazakhstan has made the difficult transition from a planned to a market economy, and from a second-level republic of the Moscow-dominated Soviet Union to a fully independent state, able to exert considerable influence within Central Asia and sometimes beyond. The remaining transition, from a one-party dominated authoritarian country to a liberal democratic state in which multiple parties compete and win elections might not occur until President Nazarbayev, popular and respected both at home and abroad, leaves the scene. The departure of the only president Kazakhstan has known since independence should open up the political environment to further transformation, though whether this actually occurs, and if so, how rapidly and in which direction, is unclear. The political and ethnic disorder in neighboring Kyrgyzstan is not encouraging for those seeking greater democracy in a region dominated by 
authoritarian presidents. This is especially true in a country as ethnically and religiously diverse as Kazakhstan, whose population consists of 130 distinct ethnic groups professing more than 40 religions.

The absence of a clear succession plan remains of concern to long-term foreign investors. Especially given events in the Middle East, foreign experts debate Nazarbayev's future intentions and status. One worry is that he would seek to remain in office indefinitely, which would make it hard to transition authority to his successor. In 2010, the legislature gave Nazarbayev the privileged legal status of "Leader of the Nation." This decision, criticized in some circles, nevertheless does provide a mechanism whereby Nazarbayev could more comprehensively withdraw from the electoral process, making it more free and fair. But his plans may not become evident until the next presidential election, scheduled for 2016. 